\title{
Factors contributing to racial differences in neurogenic orthostatic hypotension
}

\author{
Nisha Charkoudian ${ }^{1} \cdot$ Austin T. Robinson $^{2}$
}

Received: 15 January 2021 / Accepted: 17 January 2021 / Published online: 7 February 2021

(c) This is a U.S. government work and not under copyright protection in the U.S.; foreign copyright protection may apply 2021

Neurogenic orthostatic hypotension (nOH) is a characteristic manifestation of the alpha-synucleinopathies (multiple system atrophy, pure autonomic failure, Parkinson disease and dementia with Lewy bodies) $[10,14]$. However, $\mathrm{nOH}$ can occur in other disorders as well, including people with diabetic autonomic neuropathy or rare genetic disorders like familial dysautonomia. $\mathrm{nOH}$ can exacerbate the negative consequences of any of these conditions by confining the individual to a wheelchair for most of their waking hours. In some patients with baroreflex dysfunction, $\mathrm{nOH}$ coexists with supine hypertension, thus resulting in the negative sequelae and risks of both ends of the blood pressure spectrum in a single individual [14].

It has become increasingly clear in recent years that we have historically limited our understanding of mechanisms of cardiovascular and neurological diseases by conducting research primarily in groups of white men [7, 8], limiting our insight into the pathophysiology of diseases that occur in a diverse population. In this context, what we call "race" is primarily a social construct $[2,22]$. However, it is also important to evaluate biological mechanisms that might be statistically more or less prevalent in one racial group than another, and to evaluate potential reasons why this might be the case. In the United States and other countries, a history of chattel slavery, redlining, and racism have, at least in part, contributed to racial and ethnic minorities facing wealth inequality and being more likely to experience poverty and live in disadvantaged neighborhoods [2, 3, 6, 15]. These social and environmental factors influence cardiovascular disease risk by limiting access to healthful foods, safe

Nisha Charkoudian

nisha.c.simmons.civ@mail.mil

1 Thermal and Mountain Medicine Division, United States Army Research Institute of Environmental Medicine, 10 General Greene Avenue, Natick, MA 01760, USA

2 School of Kinesiology, Auburn University, Auburn, AL, USA spaces for physical activity, environmental exposures, sleep, and access to healthcare $[11,16,19]$. For example, there are racial disparities in dietary potassium intake, namely Black Americans consume less than other racial/ethnic groups [4]. Importantly, lower dietary potassium is associated with higher resting blood pressure [13]. At the other end of the blood pressure continuum is $\mathrm{nOH}$, which has been understudied in Black Americans.

In this issue of Clinical Autonomic Research, Giza and colleagues provide novel biological insight into $\mathrm{nOH}$ in non-Hispanic Black men [12]. The investigators studied cardiovascular and neurohumoral data in nine non-Hispanic Black individuals with $\mathrm{nOH}$ and compared to non-Hispanic White individuals with $\mathrm{nOH}$ and to a group of 8 non-Hispanic White healthy control subjects. They report that many of the variables relevant to $\mathrm{nOH}$, including hemodynamic and plasma norepinephrine changes with upright posture, were similar in non-Hispanic Black and non-Hispanic White patients with $\mathrm{nOH}$. However, there were marked differences between non-Hispanic Black and non-Hispanic White patients in terms of plasma renin activity and aldosterone responses to upright posture. Whereas non-Hispanic White patients and controls had marked increases in plasma renin activity and aldosterone when upright, non-Hispanic Black patients had only very small changes, and these were not statistically significant [12]. In terms of volume regulation, it is intriguing that Wenner and colleagues also reported a diminished responsiveness (reduction) in plasma renin activity and aldosterone response to sodium loading in healthy non-Hispanic Black, compared to non-Hispanic White, individuals [21].

In terms of the bigger picture of autonomic physiology research, there is evidence to suggest altered autonomic function in healthy non-Hispanic Black compared to nonHispanic White individuals [8]. Some of these data suggest that autonomic dysfunction might contribute to the increased risk of hypertension and other cardiovascular disorders that is often reported for Black communities in 
the US and other countries [1,5]. For example, Vranish and colleagues showed that the transduction of sympathetic noradrenergic nerve activity into vascular resistance was augmented in healthy young non-Hispanic Black men compared to non-Hispanic White men [20]. Similarly, Wenner and colleagues showed that the pressor response to a given increase in plasma sodium concentration (caused by hypertonic saline infusion) was augmented in young healthy non-Hispanic Black compared to non-Hispanic White men [21]. In contrast, Fonkoue and colleagues reported smaller sympathetic neural and blood pressure responses to mental stress in non-Hispanic Black men [9]. These data are consistent with the idea that "stress" is context-specific, and that chronic stressors of everyday life may result in differential neurovascular responsiveness to sympatho-excitatory stimuli associated with an acute laboratory-based mental stressor.

It is not immediately clear, for any biological variable, the extent to which biology is "inherent" or the result of external influences. What is clear is that social determinants play a large role in health outcomes influenced by biology, including blood pressure regulation $[17,18]$. In the context of areas such as epigenetics, within-life modification of the genome by a range of environmental influences, it is unclear what the term "inherent" even really means. Nevertheless, this should not hold us back from studying biological variability as one of a constellation of factors that contribute to the biomedical disparities that we are hoping to address, and mitigate, by studying differences between racial groups in the first place [2]. For our community of autonomic researchers and clinicians, the new study by Giza and colleagues provides a helpful step in this direction.

Acknowledgements We are grateful to Dr. Lucy Norcliffe-Kaufmann for critical review of this manuscript and helpful suggestions.

\section{Funding None.}

\section{Compliance with ethical standards}

Conflict of interest The views, opinions, and/or findings contained in this article are those of the authors and should not be construed as an official United States Department of the Army position, or decision, unless so designated by other official documentation. Approved for public release; distribution unlimited. Citations of commercial organizations and trade names in this report do not constitute an official U.S. Department of the Army endorsement or approval of the products or services of these organizations.

\section{References}

1. Abate NI, Mansour YH, Tuncel M, Arbique D, Chavoshan B, Kizilbash A, Howell-Stampley T, Vongpatanasin W, Victor RG (2001) Overweight and sympathetic overactivity in black Americans. Hypertension 38:379-383
2. Borrell LN, Elhawary JR, Fuentes-Afflick E, Witonsky J, Bhakta $\mathrm{N}$, Wu AHB, Bibbins-Domingo K, Rodriguez-Santana JR, Lenoir MA, Gavin JR, 3rd, Kittles RA, Zaitlen NA, Wilkes DS, Powe NR, Ziv E, Burchard EG (2021) Race and genetic ancestry in medicine: a time for reckoning with racism. $\mathrm{N}$ Engl $\mathrm{J}$ Med 384(5):474-480. https://doi.org/10.1056/NEJMms2029562

3. Braveman P, Gottlieb L (2014) The social determinants of health: it's time to consider the causes of the causes. Public Health Rep 129(Suppl 2):19-31

4. Cogswell ME, Zhang Z, Carriquiry AL, Gunn JP, Kuklina EV, Saydah SH, Yang Q, Moshfegh AJ (2012) Sodium and potassium intakes among US adults: NHANES 2003-2008. Am J Clin Nutr 96:647-657

5. Cooper RS, Wolf-Maier K, Luke A, Adeyemo A, Banegas JR, Forrester T, Giampaoli S, Joffres M, Kastarinen M, Primatesta P, Stegmayr B, Thamm M (2005) An international comparative study of blood pressure in populations of European vs. African descent. BMC Med. https://doi.org/10.1186/1741-7015-3-2

6. Diez Roux AV, Mair C (2010) Neighborhoods and health. Ann NY Acad Sci 1186:125-145

7. Drew RC, Charkoudian N, Park J (2020) Neural control of cardiovascular function in black adults: implications for racial differences in autonomic regulation. Am J Physiol Regul Integr Comp Physiol 318:R234-R244

8. Farrell MC, Giza RJ, Shibao CA (2020) Race and sex differences in cardiovascular autonomic regulation. Clin Auton Res 30:371-379

9. Fonkoue IT, Schwartz CE, Wang M (1985) Carter JR (2018) Sympathetic neural reactivity to mental stress differs in black and nonHispanic white adults. J Appl Physiol 124:201-207

10. Freeman R, Abuzinadah AR, Gibbons C, Jones P, Miglis MG, Sinn DI (2018) Orthostatic hypotension: JACC state-of-the-art review. J Am Coll Cardiol 72:1294-1309

11. Fuller-Rowell TE, Curtis DS, El-Sheikh M, Chae DH, Boylan JM, Ryff CD (2016) Racial disparities in sleep: the role of neighborhood disadvantage. Sleep Med 27-28:1-8

12. Giza RJ, Farrell MC, Arnold AC, Biaggioni I, Shibao C (2021) Clinical and neurohormonal characteristics of African Americans with neurogenic orthostatic hypotension. Clin Auton Res. In Press

13. Jackson SL, Cogswell ME, Zhao L, Terry AL, Wang CY, Wright J, Coleman King SM, Bowman B, Chen TC, Merritt R, Loria CM (2018) Association between urinary sodium and potassium excretion and blood pressure among adults in the United States: national health and nutrition examination survey, 2014. Circulation 137:237-246

14. Kaufmann H, Norcliffe-Kaufmann L, Palma JA (2020) Baroreflex dysfunction. N Engl J Med 382:163-178

15. McClure E, Feinstein L, Cordoba E, Douglas C, Emch M, Robinson W, Galea S, Aiello AE (2019) The legacy of redlining in the effect of foreclosures on Detroit residents' self-rated health. Health Place 55:9-19

16. Nardone A, Casey JA, Morello-Frosch R, Mujahid M, Balmes JR, Thakur N (2020) Associations between historical residential redlining and current age-adjusted rates of emergency department visits due to asthma across eight cities in California: an ecological study. Lancet Planet Health 4:e24-e31

17. Rao S, Segar MW, Bress AP, Arora P, Vongpatanasin W, Agusala V, Essien UR, Correa A, Morris AA, de Lemos JA, Pandey A (2020) Association of genetic West African ancestry, blood pressure response to therapy, and cardiovascular risk among selfreported black individuals in the systolic blood pressure reduction intervention trial (SPRINT). JAMA Cardiol. https://doi. org/10.1001/jamacardio.2020.6566

18. Snyder-Mackler N, Burger JR, Gaydosh L, Belsky DW, Noppert GA, Campos FA, Bartolomucci A, Yang YC, Aiello AE, O'Rand A, Harris KM, Shively CA, Alberts SC, Tung J (2020) Social 
determinants of health and survival in humans and other animals. Science 368(6493): eaax9553. https://doi.org/10.1126/scien ce.aax 9553

19. Turrell G, Haynes M, Burton NW, Giles-Corti B, Oldenburg B, Wilson LA, Giskes K, Brown WJ (2010) Neighborhood disadvantage and physical activity: baseline results from the HABITAT multilevel longitudinal study. Ann Epidemiol 20:171-181

20. Vranish JR, Holwerda SW, Young BE, Credeur DP, Patik JC, Barbosa TC, Keller DM, Fadel PJ (2018) Exaggerated vasoconstriction to spontaneous bursts of muscle sympathetic nerve activity in healthy young black men. Hypertension 71:192-198

21. Wenner MM, Paul EP, Robinson AT, Rose WC, Farquhar WB (2018) Acute $\mathrm{NaCl}$ loading reveals a higher blood pressure for a given serum sodium level in African American compared to Caucasian adults. Front Physiol 9:1354

22. Wolf ST, Jablonski NG, Kenney WL (2020) Examining "race" in physiology. Am J Physiol Heart Circ Physiol 319:H1409-H1413 